\title{
Factors associated with the prevalence of Perkinsus marinus in Crassostrea virginica from the southern Gulf of Mexico
}

\author{
M. Gullian-Klanian*, J. A. Herrera-Silveira, R. Rodríguez-Canul, \\ L. Aguirre-Macedo
}

Centro de Investigación y de Estudios Avanzados del Instituto Politécnico Nacional (CINVESTAV-IPN) Unidad Mérida, Carretera Antigua a Progreso Km 6, CP 97310 Mérida, Yucatán, Mexico

\begin{abstract}
The protozoan Perkinsus marinus is considered the most important pathogen of the eastern oyster Crassostrea virginica, causing high mortality in natural and farmed oysters on the Atlantic coast of the US. In Mexico, no serious P. marinus epizootic has been reported. This study describes the current state of $P$. marinus prevalence in Terminos Lagoon (Mexico) associated with environmental factors including salinity, temperature, ammonium, nitrate, nitrite, silica, and phosphorus. In addition, the association of physiological (hemocyte density, protein concentration) and immunological (lysozyme, agglutination) parameters with the infection were studied. The prevalence was significantly different among seasons with mean values of 70,23 , and $7 \%$ in the dry (February to May), rainy (June to September) and north-wind (October to January) seasons, respectively. Only light infection intensity (Mackin scale value <1) was observed. Prevalence of $P$. marinus was associated with seasonal salinity, phosphorus, and silica variations. Comparisons of oyster health demonstrates that the rainy and north-wind seasons are stressful periods. Redundancy analysis showed that only $34 \%$ of the variation in seasonal $P$. marinus prevalence was explained by protein concentration $(21 \%)$, lysozyme $(12 \%)$, and agglutination (1\%). Overall, the data suggest that freshwater input associated with high nutrient concentrations during the rainy and north-wind seasons has a strong negative effect on $P$. marinus prevalence and also influences the oysters' physiology. It is probable that this seasonal stress was responsible for the absence of an epizootic event in Terminos Lagoon.
\end{abstract}

KEY WORDS: Perkinsus marinus $\cdot$ Crassostrea virginica $\cdot$ Environmental control $\cdot$ Salinity $\cdot$ Silica Protein Resale or republication not permitted without written consent of the publisher

\section{INTRODUCTION}

The eastern oyster Crassostrea virginica (Gmelin, 1791) is a major fishery species off the Mexican coast on the Gulf of Mexico. The exploitation of natural beds constitutes $90 \%$ of national oyster production, mainly in the states of Veracruz and Tabasco (45.69 $\mathrm{t} \mathrm{yr}^{-1}$ ), followed by Tamaulipas and Campeche $\left(2.4 \mathrm{t} \mathrm{yr}^{-1}\right.$; Amador del Angel et al. 2003).

Terminos Lagoon, the largest coastal lagoon in Mexico, supports commercial fisheries that are the main source of income to fishermen, as well as oil extraction on the adjacent continental shelf and agricultural activities in the watershed (Yáñez-Arancibia \& Day 1988). In this region, the natural beds of Crassostrea virginica are situated on 260.4 ha and represent the oyster population of the extreme south of the Gulf of Mexico (Cabrera et al. 1999). Since 1969, oyster production has been declining (Amador del Angel et al. 2003) probably due to overfishing (MacKenzie \& Wakida-Kusunoki 1997), pollution (Gold-Bouchot et al. 1995), and variations in seasonal salinity (Cabrera et al. 1999).

The protozoan Perkinsus marinus has been extensively studied in the US due to its association with 
severe mortalities of commercial cultures of Crassostrea virginica (Burreson \& Ragone Calvo 1996). In tropical areas, the behavior of $P$. marinus has not been widely documented. In Mexico, the first report of $P$. marinus was by Burreson et al. (1994) in Tabasco after a mortality event suspected to have been caused by pollutants from an oil refinery close to CarmenPajonal-Machona and Mecoacan Lagoons. These authors demonstrated the existence of $P$. marinus in the 3 lagoons with 90 to $100 \%$ prevalence at high salinity sites $(30 \mathrm{psu})$ and $50 \%$ at low salinity sites (15 psu). Aguirre-Macedo et al. (2000) reported 50\% prevalence in 8 coastal lagoons from Veracruz, Tabasco, and Campeche except in Terminos Lagoon, with $80 \%$ prevalence in the dry season. A common characteristic of $P$. marinus in these Mexican lagoons was the high to moderate prevalence of light infection intensity (Aguirre-Macedo et al. 2000) with the exception of one location in Mecoacan Lagoon where severe infection was registered (Burreson et al. 1994).

A key characteristic of the Perkinsus marinus epizootiology is the influence of environmental conditions on disease progression. Water temperature and salinity are the main environmental factors affecting the transmission and pathogenicity of the parasite in temperate climates (Ragone Calvo et al. 2000, Ragone Calvo \& Burreson 2003, Audemard et al. 2006). It has been noted in Chesapeake Bay (USA) that high temperature and salinity are associated with parasite proliferation and disease outbreaks (Burreson \& Ragone Calvo 1996). However, under cool water temperatures $\left(10\right.$ to $\left.15^{\circ} \mathrm{C}\right)$ and/or low salinity (less than $9 \mathrm{psu}$ ), the disease prevalence and the infection intensity remain low (Chu \& La Peyre 1993). Environmental factors are also considered stressors because they influence the physiological condition of both the host and the parasite (Lenihan et al. 1999). The relative importance of these environmental conditions on $P$. marinus and its host's response is not well known in tropical areas of the Gulf of Mexico.

The main objective of the present study was to investigate the behavior of Perkinsus marinus on the tropical coast of the Gulf of Mexico with particular emphasis on (1) estimating the prevalence and intensity of infection of $P$. marinus in Terminos Lagoon during 3 seasons, (2) identifying the possible influence of the environmental factors on the prevalence of $P$. marinus, and (3) studying the oyster's physiological and immunological parameters associated with $P$. marinus infection in this tropical area.

\section{MATERIALS AND METHODS}

Study area. Terminos Lagoon is located in Campeche, $18^{\circ} 20^{\prime}$ to $19^{\circ} 00^{\prime} \mathrm{N}$ and $91^{\circ} 10^{\prime}$ to $92^{\circ} 00^{\prime} \mathrm{W}$ (Fig. 1). It is approximately $70 \mathrm{~km}$ long and $30 \mathrm{~km}$ wide with a mean depth of $3.5 \mathrm{~m}$ and a surface area of 170000 ha. The lagoon is connected to the sea by 2 inlets: Carmen Inlet on the western side ( $4 \mathrm{~km}$ long) and Puerto Real Inlet on the eastern side $(3.3 \mathrm{~km})$. The climate in this tropical region includes 3 distinct seasons: the north-wind season from October to January, the dry season from February to May, and the rainy season from June to September (Yáñez-Arancibia \& Day 1988). The temperature shows low seasonal variations $\left(27\right.$ to $\left.33^{\circ} \mathrm{C}\right)$; however, the salinity varies between seasons due to river runoff. Three high-flow rivers (Candelaria, Chumpan, and Palizada) provide most of the freshwater input to the lagoon $\left(378 \mathrm{~m}^{3} \mathrm{~s}^{-1}\right)$ with weak circulation (Yáñez-Arancibia et al. 1983). Half of the water volume is renewed every $9 \mathrm{~d}$, mostly as a result of tidal exchange. The tide is mainly diurnal, with a mean range of $0.3 \mathrm{~m}$ (David \& Kjerfve 1998). Oysters are subtidal to about $1 \mathrm{~m}$ depth in the rainy season and 0.3 to $0.5 \mathrm{~m}$ in the dry season. The western side of the Lagoon is biologically more productive and accommodates most oyster beds (MacKenzie \& Wakida-Kusunoki 1997, Bach et al. 2005). The spawning activity is not strictly associated with different seasons. There are 2 annual spawning periods: March to May (dry season) and September to November (rainy and north-wind seasons), both in the salinity range of 12 to $25 \mathrm{psu}$ and 28 to $30^{\circ} \mathrm{C}$ (Rogers \& García-Cubas 1981, Martínez et al. 1995).

Sample collection and processing. Oyster samples were hand-collected from 7 sites in the Terminos

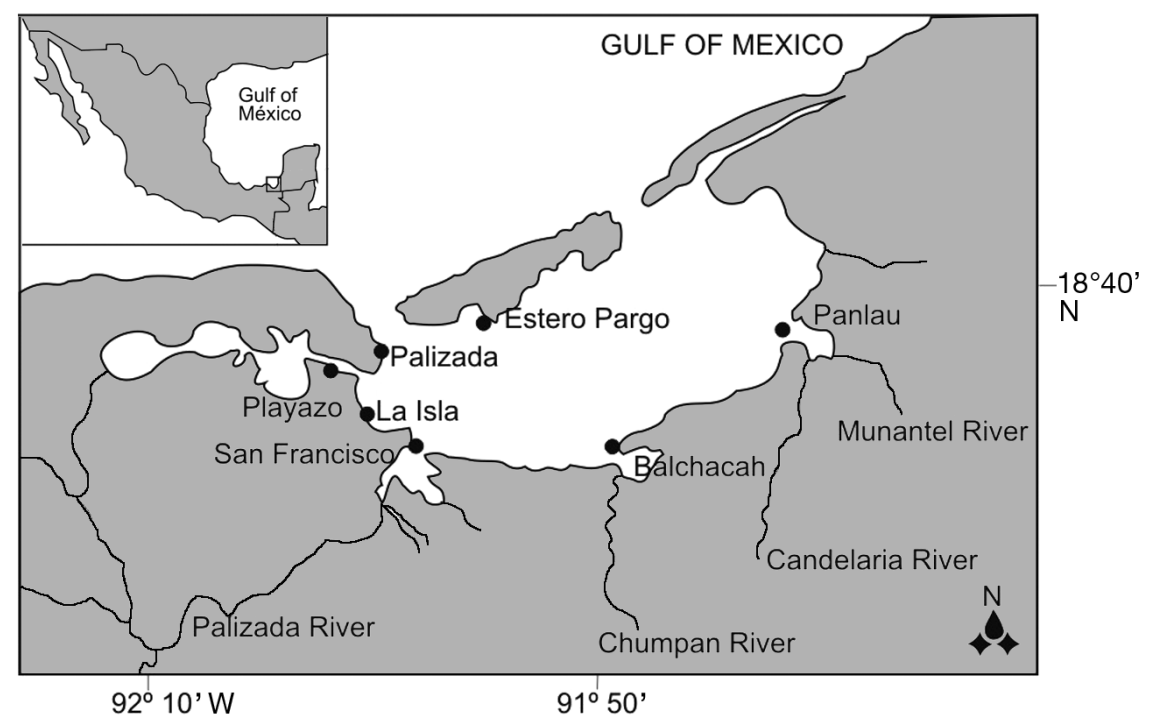

Fig. 1. Terminos Lagoon, Gulf of Mexico, showing the 7 sampling sites 
Lagoon (Fig. 1) in the 'dry' (5 April 2005), 'rainy' (15 September 2005), and 'north-wind' (8 January 2006) seasons. These sampling months were selected because they reflect the environmental changes that occur at the end of each seasonal period. At each site, 45 oysters and 3 water samples were collected. In addition, temperature $\left({ }^{\circ} \mathrm{C}\right.$ ) and salinity (psu) were taken in situ using a mercury thermometer and refractometer, respectively. Water samples were collected using Van Dorn bottles. The samples were stored at $10^{\circ} \mathrm{C}$ and transported to the Primary Production Laboratory of CINVESTAV. The oysters were placed into coolers containing cold ice packs and transported to the Aquatic Pathology Laboratory at CINVESTAV. In the laboratory, oysters were placed in tanks at similar salinity to their collection site.

Additional oyster samples (length $=6.35 \pm 0.30 \mathrm{~cm}$ ) were randomly taken from 25 points in a $5 \mathrm{~m}^{2}$ area from each site until a tank (ca. 70 l) was full. Next, 100 oysters were classified as alive, empty shells (dead oysters with no soft tissue remaining, but with valves still attached at the hinge and little or no fouling), and gapers (dead oysters with valves attached containing soft tissue) to estimate in situ inter-seasonal mortality. Percentage mortality was calculated as [dead oysters (gapers + empty shells)/total oysters] $\times 100$.

Oyster size and condition index (CI). Measurements of oysters were determined as height (tip of the bill to the hinge, along a line touching the ventral edge of the adductor muscle scar), length (measured on a line perpendicular to the height line through the anterior edge of the adductor muscle scar), and width (measured as the greatest distance between the 2 shells along a line perpendicular to both height and length; Galtsoff 1964). Following hemolymph withdrawal (see 'Hemolymph processing and hemocyte density'), oysters were shucked, and soft tissue was weighted to obtain the total wet weight. The CI was estimated using the formula proposed by Choi et al. (2002): CI = [wet tissue weight/(height $\times$ width $\times$ length) $] \times 100$.

Prevalence and weighted prevalence of Perkinsus marinus. Infection intensity of $P$. marinus was assessed using the culture method of Ray (1966). Briefly, a small section of mantle, gill, and rectum $(0.30 \mathrm{~g})$ was removed from each oyster, placed in thioglycollate medium (FTM), and incubated at $24^{\circ} \mathrm{C}$ in the dark for $5 \mathrm{~d}$. After staining with $0.5 \%$ Lugol's iodine, the tissue was examined under the light microscope at $400 \times$ magnification for the presence of $P$. marinus hypnospores. Infection intensity was ranked on a 0 to 5 point scale from uninfected to heavily infected for calculation of weighted prevalence (Mackin 1962).

Another sample of tissue (0.30 g) containing mantle, gill, and rectum was preserved in $95 \%$ ethanol and used to determine the prevalence by simple polymerase chain reaction (PCR) assay. Extraction of DNA was carried out using the phenol:chloroform method (Sambrook et al. 1989). The tissue samples were lysed in the presence of $10 \%$ sodium dodecyl sulfate (SDS) and 30\% Proteinase $\mathrm{K}$. The DNA was concentrated with 7.5 M ammonium acetate. PCR primers (5'-CACTTGTATTGTGA ACCC-3', 300F and 5'-TTGGTGACATCTCCAAATG AC-3', 300R) that amplify a 307 bp target region within the NTS domain between the $5 \mathrm{~S}$ and small subunit $\mathrm{rDNa}$ (SSU rRNA) genes from Perkinsus marinus were used for the detection of the parasite (Marsh et al. 1995). All samples were subjected to identical reaction conditions in a Perkin Elmer 2400 thermal cycler. Taq DNA polymerase (1.5 U) was used in a $25 \mu \mathrm{l}$ reaction with the manufacturer's reaction buffer. In addition, each assay contained $1.5 \mathrm{mM} \mathrm{MgCl}_{2}, 200 \mu \mathrm{M}$ of each dNTP, $1 \mu \mathrm{M}$ of each primer, and $1 \mu \mathrm{l}(1 \mu \mathrm{g})$ of template DNA. The amplification profile described by Robledo et al. (1999) was used instead of the conditions described by Marsh et al. (1995), because the gradient of temperature significantly reduces the $P$. marinus amplification time. The temperature profile was 35 cycles at $91^{\circ} \mathrm{C}$ for $1 \mathrm{~min}, 58^{\circ} \mathrm{C}$ for $1 \mathrm{~min}$ (plus $1 \mathrm{~s}$ per cycle), and $72^{\circ} \mathrm{C}$ for $1 \mathrm{~min}$ (plus $2 \mathrm{~s}$ per cycle). The presence of the P. marinus-specific NTS target sequence was confirmed by sequencing the 307 bp PCR product, showing $99 \%$ similarity with the S78416 P. marinus sequence (Marsh et al. 1995). Since Aguirre-Macedo et al. (2000) had reported light infection in Terminos Lagoon and Robledo et al. (1998) described the sensibility difference in light infection between PCR and FTM, we analyzed the 945 samples by both techniques (PCR, FTM). The results obtained from PCR were used to estimate prevalence because they showed high sensibility (Table 1). The Ray/Mackin assay was used to estimate weighted prevalence because of its simplicity and accuracy at the population level (Bushek et al. 1994). Although FTM is a semi-quantitative method, it had been mainly used in fieldwork because of the large number of samples needed to estimate intensity and the use of the conventional Mackin's scale to compare results (Karolus et al. 2000, Carnegie \& Burreson 2005).

The remaining tissues (digestive gland, mantle, intestine, labial palps) were also fixed in Davidson's fixative for histological examination.

Hemolymph processing and hemocyte density. The oysters were scrubbed clean of fouling organisms, and a grinder was used to notch the shells at the posterior edge adjacent to the adductor muscle. Hemolymph was withdrawn from the adductor muscle with a $3 \mathrm{ml}$ syringe and a 22 gauge needle. To estimate the total hemocyte count, $10 \mu \mathrm{l}$ of hemolymph were fixed in an equal volume of Baker's formol, containing $2 \%$ sodium chloride. Total cell counts were performed in duplicate using a Neubauer chamber. 
Table 1. Perkinsus marinus infecting Crassostrea virginica. Prevalence and weighted prevalence of P. marinus, determined by thioglycollate medium (FTM), in oysters from Terminos Lagoon, Mexico

\begin{tabular}{|c|c|c|c|c|c|c|c|c|c|c|}
\hline \multirow[t]{3}{*}{ Sampling site } & \multirow[t]{3}{*}{ Location } & \multicolumn{3}{|c|}{ Dry season $(\mathrm{n}=45)$} & \multicolumn{3}{|c|}{ Rainy season $(n=45)$} & \multicolumn{3}{|c|}{ North-wind season $(n=45)$} \\
\hline & & \multicolumn{2}{|c|}{$\begin{array}{l}\text { Percent } \\
\text { infected }\end{array}$} & \multirow[t]{2}{*}{$\begin{array}{c}\text { Weighted } \\
\text { prevalence }\end{array}$} & \multicolumn{2}{|c|}{$\begin{array}{l}\text { Percent } \\
\text { infected }\end{array}$} & \multirow[t]{2}{*}{$\begin{array}{c}\text { Weighted } \\
\text { prevalence }\end{array}$} & \multicolumn{2}{|c|}{$\begin{array}{l}\text { Percent } \\
\text { infected }\end{array}$} & \multirow[t]{2}{*}{$\begin{array}{c}\text { Weighted } \\
\text { prevalence }\end{array}$} \\
\hline & & PCR & FTM & & PCR & FTM & & PCR & FTM & \\
\hline Estero Pargo & $18^{\circ} 40.04^{\prime} \mathrm{N}, 91^{\circ} 44.32^{\prime} \mathrm{W}$ & 60 & 47 & 0.47 & 7 & 7 & 0.07 & 4 & 2 & 0.02 \\
\hline Palizada & $18^{\circ} 30.17^{\prime} \mathrm{N}, 91^{\circ} 51.35^{\prime} \mathrm{W}$ & 69 & 60 & 0.60 & 18 & 13 & 0.13 & 4 & 2 & 0.02 \\
\hline La Isla & $18^{\circ} 30.47^{\prime} \mathrm{N}, 91^{\circ} 47.60^{\prime} \mathrm{W}$ & 73 & 69 & 0.69 & 22 & 11 & 0.11 & 4 & 0 & 0.00 \\
\hline Balchacah & $18^{\circ} 25.55^{\prime} \mathrm{N}, 91^{\circ} 31.21^{\prime} \mathrm{W}$ & 96 & 89 & 0.89 & 24 & 18 & 0.18 & 0 & 0 & 0.00 \\
\hline San Francisco & $18^{\circ} 29.34^{\prime} \mathrm{N}, 91^{\circ} 46.27^{\prime} \mathrm{W}$ & 51 & 29 & 0.29 & 40 & 33 & 0.33 & 7 & 0 & 0.00 \\
\hline Playaso & $18^{\circ} 34.04^{\prime} \mathrm{N}, 91^{\circ} 53.15^{\prime} \mathrm{W}$ & 87 & 71 & 0.71 & 33 & 22 & 0.22 & 16 & 9 & 0.09 \\
\hline Panlau & $18^{\circ} 37.30^{\prime} \mathrm{N}, 91^{\circ} 17.22^{\prime} \mathrm{W}$ & 53 & 47 & 0.47 & 13 & 7 & 0.09 & 13 & 0 & 0.00 \\
\hline
\end{tabular}

Protein concentration was determined by the method of Lowry (1951) with the sample diluted 10fold in deionized water. Hemolymph $(0.25$ to $0.5 \mathrm{ml})$ from each individual oyster was placed in a plastic microfuge tube and centrifuged at $2900 \times g$ for $5 \mathrm{~min}$. The serum was held at $4^{\circ} \mathrm{C}$ for less than $1 \mathrm{wk}$ before being tested for protein, lysozyme, and agglutinin content. Protein concentration of each sample was calculated from a standard curve generated from dilutions of bovine serum albumin ( 0 to $10 \mathrm{mg} \mathrm{ml}^{-1}$ ).

Agglutination by hemolymph serum was tested using $0.9 \% \mathrm{NaCl}$-washed sheep erythrocytes (sheep red blood cells, SRBC). Hemolymph serum samples were diluted 1:1 in Alsever's solution. Serial 2-fold dilutions of $50 \mu \mathrm{l}$ serum in 96-well microtiter plates were assayed with $50 \mu \mathrm{l}$ of $\operatorname{SRBC}\left(7 \times 10^{6} \mathrm{cell} \mathrm{ml}^{-1}\right)$ suspension in $8.5 \mathrm{psu}$ artificial seawater (Fisher \& DiNuzzo 1991). Microtiter plates were recorded as the reciprocal of the highest dilution showing positive agglutination and expressed as $\log _{2}$ values to reflect the 2-fold serial dilutions.

Lysozyme was quantified by measuring the ability of oyster serum to degrade a suspension of the bacterium Micrococcus lysodeikticus (Sigma). The bacteria were re-suspended in potassium phosphate buffer $(0.1 \mathrm{M}$, $0.09 \% \mathrm{NaCl}$ ), and the optical density was adjusted to 0.7 absorbance units at $560 \mathrm{~nm}$ with a spectrophotometer. Serum $\left(25 \mu \mathrm{l}\right.$ well $\left.^{-1}\right)$ and $175 \mu \mathrm{l}$ of M. lysodeikticus suspension were placed in a 96-well plate. The decrease in turbidity was traced for $4 \mathrm{~min}$ at $560 \mathrm{~nm}$. The rates of degradation were compared to a curve of standard solutions prepared from hen egg-white lysozyme (0 to $30 \mu \mathrm{g} \mathrm{ml}^{-1}$; Sigma). Lysozyme activity was expressed in $\mu \mathrm{g} \mathrm{ml}^{-1}$ of hen egg-white lysozyme equivalent and adjusted to protein concentration.

Water quality. For analysis of dissolved inorganic nutrients, the water samples were filtered through a $0.45 \mu \mathrm{m}$ membrane filter. Ammonium $\left(\mathrm{NH}_{4}^{+}\right)$was determined by the phenol hypochlorite method (Solorzano \& Sharp 1980). Soluble reactive silica (SRSi) was determined by the molybdenum blue method, with ascorbic acid as a reductant. Nitrogen in the form of nitrite $\left(\mathrm{NO}_{2}{ }^{-}\right)$was determined by sulfanilamide in an acid solution method, and nitrate $\left(\mathrm{NO}_{3}{ }^{-}\right)$was measured as $\mathrm{NO}_{2}^{-}$after its reduction in a $\mathrm{Cd}-\mathrm{Cu}$ column. Soluble reactive phosphorus (SRP) was determined using the molybdenum blue method (Strickland \& Parsons 1972).

Statistical methods. Two-way analysis of variance (ANOVA) was conducted to relate the response variable (prevalence) to the main effects of the season and sampling sites and to test for possible interactions. Bonferroni/Dunn post hoc tests were used to differentiate between overall season and site means. Physiological data were processed using a nonparametric Kruskal-Wallis test. The significance between PCR and FTM methods was assessed by a chi-squared test. Multivariate statistical methods were used to determine the variability of environmental and physiological parameters. Canonical variant analysis (CVA) was used to assess whether the environmental parameters were sufficiently different to discriminate the 3 seasons (Ter Braak \& Smilauer 2002). The same analysis was used to classify the oysters from the different sites into groups based on their physiological characteristics. The forward selection procedure was performed to select the predictors included in the CVA plot. The individual predictors were accepted with a type I error probability estimated less than $\alpha / \mathrm{Nc}_{\mathrm{c}}$ (Bonferroni correction), where $\mathrm{Nc}_{\mathrm{c}}$ is the number of independent variables used in the analysis (Legendre \& Legendre 1998). Redundancy analysis (RDA; Leps \& Smilauer 2003) was used to determine the amount of variability in the Perkinsus marinus infection data explained by the physiological condition of the oysters. A Monte Carlo test with 5000 permutations was used to select the variables to include in the RDA. The condition index was used as a co-variable to control oyster size over the physiological variables. To describe the dependence of $P$. marinus prevalence (response variable) on the environmental parameters, we used a 
generalized linear model (GLM) that made less specific assumptions about the variance compared to the general linear regression method (McCullagh \& Nelder 1989). Analyses were performed using CANOCO 4.5 software, and plots were made with the Canodraw 4.0 graphics software (Ter Braak \& Smilauer 2002).

\section{RESULTS}

\section{Prevalence and weighted prevalence}

Prevalence (percent infected) determined by PCR and intensity (weighted prevalence) determined by FTM is shown in Table 1. There were differences in the number of oysters infected in the 3 seasons (2-way ANOVA $\left._{i} F_{(6,2)}=109, \mathrm{p}<0.0001\right)$ with 70,23 , and $7 \%$ prevalence in the dry, rainy, and north-wind seasons respectively. No significant differences were registered in the interaction of site and season $\left(F_{(6,2)}=1.87\right.$, $p=0.066)$ indicating that independent of the site, prevalence increased in the dry season, declined in the rainy season, and became lower in the north-wind season. Spherical black cells from 10 to $200 \mu$ m diameter typical of Perkinsus marinus were observed as a result of the FTM assay. PCR and FTM differed significantly by 104 samples $\left(\chi_{(0.95,1)}^{2}=49.9, R^{2}=0.86\right)$ in prevalence estimation. Only light infection intensity was registered (Mackin scale value $<1$ ) with no significant difference $\left(\right.$ ANOVA $\left._{i} F_{(6,2)}=1.88, \mathrm{p}=0.100\right)$ among sites (Table 1). No severe histological changes were found in the oysters with the exception of Nematopsis spp. in $8 \%$ of samples.

\section{Environmental data and mortality}

The seasonal variation of environmental parameters and oyster mortality are shown in Tables 2 \& 3, respectively. The environmental conditions were sig-

Table 3. Crassostrea virginica. Percentage mortality in Terminos Lagoon, Mexico

\begin{tabular}{|lccc|}
\hline \multirow{2}{*}{ Site } & \multicolumn{3}{c|}{$\begin{array}{c}\text { Season } \\
\text { Rainy }\end{array}$} \\
\cline { 4 - 4 }$(\mathrm{n}=100)$ & $(\mathrm{n}=100)$ & $\begin{array}{c}\text { North-wind } \\
(\mathrm{n}=100)\end{array}$ \\
\hline Estero Pargo & 0 & 5 & 9 \\
Palizada & 13 & 40 & 30 \\
La Isla & 21 & 43 & 45 \\
Balchacah & 12 & 61 & 52 \\
San Francisco & 22 & 30 & 36 \\
Playaso & 10 & 29 & 39 \\
Panlau & 18 & 40 & 48 \\
\hline
\end{tabular}

Table 2. Environmental parameters (mean \pm SD) measured at 7 sites in Terminos Lagoon, Mexico. SRP: soluble reactive phosphorus; SRSi: soluble reactive silica

\begin{tabular}{|c|c|c|c|c|c|c|c|}
\hline Site & $\begin{array}{c}\text { Temperature } \\
\left({ }^{\circ} \mathrm{C}\right)\end{array}$ & $\begin{array}{c}\text { Salinity } \\
\text { (psu) }\end{array}$ & $\begin{array}{l}\mathrm{NO}_{3}^{-} \\
(\mathrm{mM})\end{array}$ & $\begin{array}{l}\mathrm{NO}_{2}^{-} \\
(\mathrm{mM})\end{array}$ & $\begin{array}{l}\mathrm{NH}_{4}^{+} \\
(\mathrm{mM})\end{array}$ & $\begin{array}{l}\text { SRP } \\
(\mathrm{mM})\end{array}$ & $\begin{array}{l}\text { SRSi } \\
(\mathrm{mM})\end{array}$ \\
\hline \multicolumn{8}{|l|}{ Dry season } \\
\hline Estero Pargo & $32 \pm 0.0$ & $45 \pm 0.0$ & $1.14 \pm 0.08$ & $0.18 \pm 0.16$ & $10.0 \pm 1.41$ & $0.12 \pm 0.09$ & $50.09 \pm 0.72$ \\
\hline Palizada & $30 \pm 0.0$ & $25 \pm 0.5$ & $2.07 \pm 0.48$ & $0.30 \pm 0.16$ & $14.19 \pm 1.08$ & $0.36 \pm 0.14$ & $70.86 \pm 0.45$ \\
\hline La Isla & $28 \pm 0.5$ & $28 \pm 0.0$ & $6.14 \pm 0.22$ & $0.07 \pm 0.10$ & $13.92 \pm 0.27$ & $0.06 \pm 0.04$ & $68.47 \pm 0.16$ \\
\hline Balchacah & $28 \pm 0.0$ & $30 \pm 0.6$ & $1.48 \pm 0.18$ & $0.3 \pm 0.03$ & $42.30 \pm 6.29$ & $0.26 \pm 0.26$ & $85.31 \pm 0.60$ \\
\hline San Francisco & $28 \pm 0.0$ & $1 \pm 0.6$ & $3.32 \pm 1.30$ & $0.16 \pm 0.15$ & $20.85 \pm 2.49$ & $0.41 \pm 0.11$ & $112.04 \pm 3.17$ \\
\hline Playaso & $28 \pm 0.0$ & $34 \pm 0.8$ & $3.57 \pm 2.38$ & $0.71 \pm 1.22$ & $10.53 \pm 1.08$ & $0.05 \pm 0.01$ & $53.96 \pm 0.45$ \\
\hline Panlau & $28 \pm 0.5$ & $30 \pm 0.0$ & $1.95 \pm 0.58$ & $0.01 \pm 0.00$ & $9.82 \pm 0.67$ & $0.06 \pm 0.05$ & $101.20 \pm 13.61$ \\
\hline \multicolumn{8}{|l|}{ Rainy season } \\
\hline Estero Pargo & $32 \pm 0.0$ & $23 \pm 2.3$ & $2.60 \pm 0.40$ & $1.13 \pm 0.04$ & $20.33 \pm 11.42$ & $1.47 \pm 0.40$ & $107.37 \pm 2.10$ \\
\hline Palizada & $30 \pm 0.0$ & $5 \pm 0.0$ & $2.69 \pm 0.67$ & $1.14 \pm 0.08$ & $63.35 \pm 59.31$ & $1.48 \pm 0.03$ & $223.07 \pm 1.45$ \\
\hline La Isla & $30 \pm 0.0$ & $3 \pm 2.9$ & $2.46 \pm 0.35$ & $1.14 \pm 0.15$ & $64.82 \pm 72.23$ & $1.52 \pm 0.08$ & $152.80 \pm 15.65$ \\
\hline Balchacah & $28 \pm 0.6$ & $2 \pm 2.5$ & $7.14 \pm 0.27$ & $1.42 \pm 0.05$ & $75.87 \pm 50.39$ & $1.90 \pm 0.03$ & $140.60 \pm 1.55$ \\
\hline San Francisco & $28 \pm 0.0$ & $1 \pm 1.5$ & $4.21 \pm 0.03$ & $1.29 \pm 0.01$ & $28.50 \pm 19.06$ & $1.46 \pm 0.05$ & $157.33 \pm 13.99$ \\
\hline Playaso & $31 \pm 0.0$ & $12 \pm 1.7$ & $1.94 \pm 0.06$ & $1.01 \pm 0.00$ & $22.76 \pm 9.44$ & $1.41 \pm 0.05$ & $187.23 \pm 4.58$ \\
\hline Panlau & $28 \pm 0.0$ & $7 \pm 5.8$ & $2.92 \pm 0.32$ & $1.21 \pm 0.09$ & $18.34 \pm 13.42$ & $1.84 \pm 0.08$ & $208.13 \pm 4.23$ \\
\hline \multicolumn{8}{|c|}{ North-wind season } \\
\hline Estero Pargo & $26 \pm 0.0$ & $26 \pm 0.0$ & $2.25 \pm 0.67$ & $0.14 \pm 0.04$ & $9.76 \pm 4.24$ & $0.21 \pm 0.16$ & $74.63 \pm 5.23$ \\
\hline Palizada & $27 \pm 0.0$ & $7 \pm 1.2$ & $2.00 \pm 0.16$ & $0.05 \pm 0.04$ & $0.25 \pm 0.13$ & $0.05 \pm 0.02$ & $127.07 \pm 5.51$ \\
\hline La Isla & $26 \pm 0.0$ & $3 \pm 0.0$ & $5.60 \pm 0.69$ & $0.14 \pm 0.02$ & $0.39 \pm 0.25$ & $0.44 \pm 0.13$ & $112.27 \pm 4.98$ \\
\hline Balchacah & $24 \pm 0.0$ & $15 \pm 0.0$ & $2.22 \pm 0.66$ & $0.26 \pm 0.09$ & $2.61 \pm 1.23$ & $0.10 \pm 0.07$ & $125.45 \pm 1.73$ \\
\hline San Francisco & $23 \pm 0.5$ & $3 \pm 1.0$ & $6.82 \pm 0.25$ & $0.29 \pm 0.09$ & $0.10 \pm 0.00$ & $0.97 \pm 0.65$ & $139.43 \pm 5.66$ \\
\hline Playaso & $26 \pm 0.0$ & $10 \pm 1.3$ & $1.57 \pm 0.29$ & $0.22 \pm 0.15$ & $3.77 \pm 3.18$ & $0.31 \pm 0.18$ & $113.07 \pm 9.90$ \\
\hline Panlau & $25 \pm 0.0$ & $5 \pm 0.0$ & $2.79 \pm 0.42$ & $0.31 \pm 0.09$ & $1.73 \pm 0.63$ & $0.13 \pm 0.12$ & $145.87 \pm 0.29$ \\
\hline
\end{tabular}




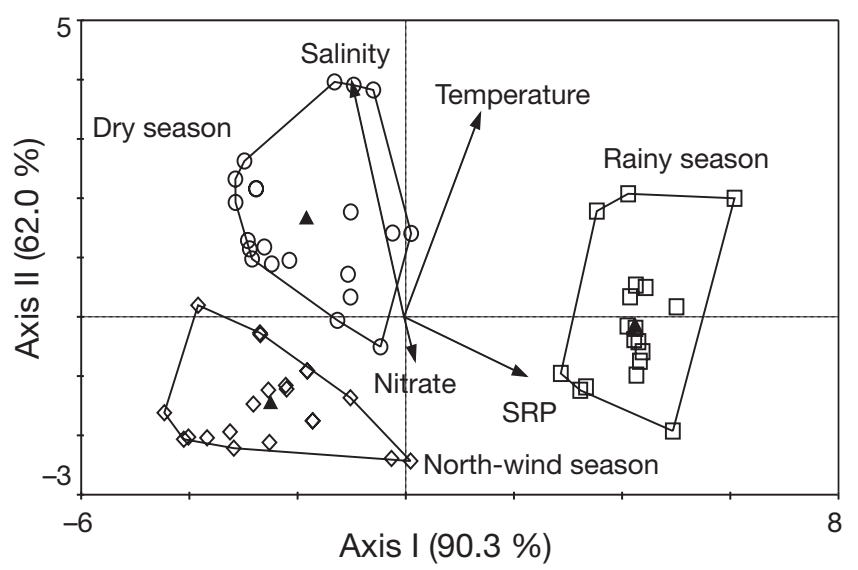

Fig. 2. Canonical variant analysis (CVA) based on 7 environmental parameters. Canonical scores of the 4 significant environmental variables (arrows) plotted on the first 2 discriminating axes (Monte Carlo test with 5000 permutations, $\mathrm{p}=0.001$ ). Eigenvalues shown in parentheses. The diagram was adjusted by differentiating line style for sample group envelopes. SRP: soluble reactive phosphorus; $\boldsymbol{\Delta}$ : centroids of each data group; $\square$ : rainy season samples; $\diamond$ : north-wind season samples; O: dry season samples

nificantly different between seasons (Fig. 2). SRP, temperature, salinity, and nitrate showed the highest seasonal variation $(84,52,11$, and $6 \%$, respectively), contributing to the CVA variance. Temperature variation was clearly related to different climatic periods. In the dry season, when the prevalence was high, the temperature reached $29 \pm 2^{\circ} \mathrm{C}$ (mean $\pm \mathrm{SD}$ ). The highest temperature $\left(30 \pm 2^{\circ} \mathrm{C}\right)$ was recorded in the rainy season and the lowest $\left(25 \pm 1^{\circ} \mathrm{C}\right)$ in the northwind season. SRP exhibited the highest concentration $(1.58 \pm 0.20 \mu \mathrm{M})$ in the dry season and the lowest in rainy season $(0.19 \pm 0.15 \mu \mathrm{M})$ contrary to $\mathrm{SRSi}$, which had the highest concentration in the rainy season $(168 \pm 40 \mu \mathrm{M})$ and the lowest in the dry season $(77.4$ $\pm 23 \mu \mathrm{M})$. Salinity exhibited marked seasonal variations, ranging from $8 \pm 8$ psu in the rainy season to
$29 \pm 10 \mathrm{psu}$ in the dry season. The geographic position of the oyster bed determined the salinity difference among the sampling sites and also the high standard deviation (Fig. 1, Table 2). Results of the GLM showed that annual Perkinsus marinus prevalence was positively associated with salinity $\left(F_{(1,61)}=\right.$ $31.79, \mathrm{p}<0.00001, \mathrm{R}^{2}=0.40$ ), and negatively associated with $\operatorname{SRSi}\left(F_{(1,61)}=23.47, \mathrm{p}=0.00002, \mathrm{R}^{2}=0.30\right)$, and $\operatorname{SRP}\left(F_{(1,61)}=6.17, \mathrm{p}=0.01, \mathrm{R}^{2}=0.20\right.$; Fig. 3$)$. Temperature, ammonium, nitrite, and nitrate concentration were not significant predictors.

\section{Physiological parameters}

$\mathrm{CI}$ and hemocyte concentration (THC) showed a seasonal pattern for all sampling sites (Table 4 ). The highest $\mathrm{CI}$ was observed in the dry season (median $=5.10$ ) and decreased in the rainy season $(2.80 ; \mathrm{p}<0.0001)$. The THC showed the same pattern, with a median of $3.0 \times 10^{6}$ and $1.0 \times 10^{6}$ cells ml $^{-1}$ in the dry and rainy seasons, respectively. Protein and lysozyme concentrations showed a strong seasonal pattern at all sites (Table 4), with the highest concentrations in the dry season (medians $=5.39$ and $13.72 \mathrm{mg} \mathrm{ml}^{-1}$, respectively) and the lowest in rainy season (protein = $0.66 \mathrm{mg} \mathrm{ml}^{-1}$, lysozyme $=4.98 \mathrm{mg} \mathrm{ml}^{-1}$ ). Agglutination had only a significant seasonal variation in the San Francisco and Panlau sites (Table 4). From RDA, only $34.0 \%$ of the seasonal Perkinsus marinus infection intensity can be explained by the canonical axis. The variables that explained the most consecutive variance (conditional effects) were protein concentration $(21 \%$ of total inertia), lysozyme (12\%), and agglutination $(1 \%)$. The hemocyte density was not a significant predictor. CVA using 4 physiological variables (protein, lysozyme, THC, agglutination) showed that oysters from different sampling sites aggregated into a single population independent of their geographic origin (Fig. 4).
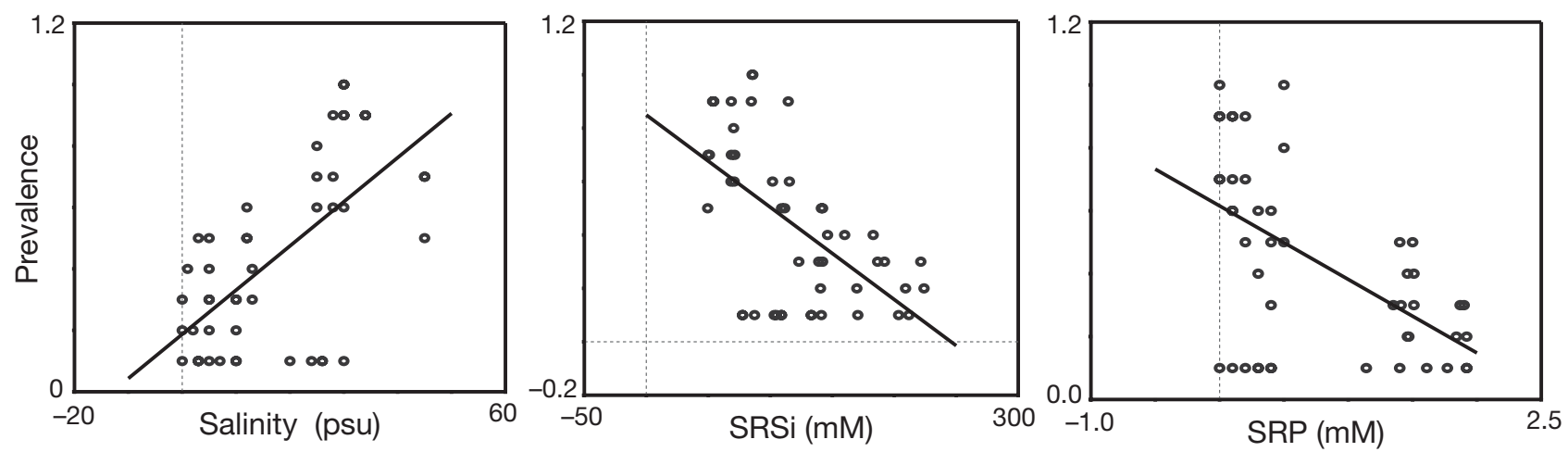

Fig. 3. Perkinsus marinus. Generalized linear models (GLM) of prevalence, and environmental variables. SRSi: soluble reactive silica; SRP: soluble reactive phosphorus 
Table 4. Crassostrea virginica. Seasonal effects on physiological and immunological parameters of oysters collected in Terminos Lagoon, Mexico. Different letters indicate significant differences between groups of each parameter. Statistical analysis was performed using a Kruskal-Wallis test. THC: hemocyte concentration

\begin{tabular}{|c|c|c|c|c|}
\hline $\begin{array}{l}\text { Site } \\
\text { Parameter }\end{array}$ & $\begin{array}{c}\text { Dry } \\
\text { season } \\
(\mathrm{n}=315) \\
\text { Median }\end{array}$ & $\begin{array}{l}\text { Rainy } \\
\text { season } \\
(\mathrm{n}=315) \\
\text { Median }\end{array}$ & $\begin{array}{c}\text { North-wind } \\
\text { season } \\
(\mathrm{n}=315) \\
\text { Median }\end{array}$ & $\mathrm{p}$ \\
\hline \multicolumn{5}{|l|}{ Balchacah } \\
\hline Condition index & $5.50 \mathrm{a}$ & $2.40 \mathrm{~b}$ & $5.30 \mathrm{a}$ & $<0.0001$ \\
\hline Agglutination titer & $5.30 \mathrm{a}$ & $4.90 \mathrm{a}$ & $5.60 \mathrm{a}$ & 0.2156 \\
\hline Protein $\left(\mathrm{mg} \mathrm{l}^{-1}\right)$ & $6.11 \mathrm{a}$ & $0.54 \mathrm{~b}$ & $0.65 \mathrm{~b}$ & $<0.0001$ \\
\hline Lysozyme $\left(\mathrm{mg} \mathrm{l}^{-1}\right)$ & $17.42 \mathrm{a}$ & $3.54 \mathrm{~b}$ & $4.88 \mathrm{C}$ & $<0.0001$ \\
\hline THC (cell ml $\left.{ }^{-1}\right)$ & $3 \times 10^{6} \mathrm{a}$ & $7.1 \times 10^{5} \mathrm{~b}$ & $2.8 \times 10^{6} \mathrm{a}$ & $<0.0001$ \\
\hline \multicolumn{5}{|l|}{ Estero Pargo } \\
\hline Condition index & $5.80 \mathrm{a}$ & $2.00 \mathrm{~b}$ & $3.80 \mathrm{c}$ & $<0.0001$ \\
\hline Agglutination titer & $4.90 \mathrm{a}$ & $4.90 \mathrm{a}$ & $5.30 \mathrm{a}$ & 0.1462 \\
\hline Protein $\left(\mathrm{mg} \mathrm{l}^{-1}\right)$ & $6.78 \mathrm{a}$ & $6.87 \mathrm{a}$ & $5.78 \mathrm{~b}$ & 0.0200 \\
\hline Lysozyme $\left(\mathrm{mg} \mathrm{l}^{-1}\right)$ & $5.61 \mathrm{a}$ & $4.43 \mathrm{~b}$ & $4.06 \mathrm{~b}$ & $<0.0001$ \\
\hline THC (cell ml $\left.{ }^{-1}\right)$ & $2.6 \times 10^{6} \mathrm{a}$ & $8.9 \times 10^{5} \mathrm{~b}$ & $3.2 \times 10^{6} \mathrm{a}$ & $<0.0001$ \\
\hline \multicolumn{5}{|l|}{ La Isla } \\
\hline Condition index & $3.60 \mathrm{a}$ & $4.30 \mathrm{~b}$ & $4.30 \mathrm{~b}$ & 0.0147 \\
\hline Agglutination titer & $5.30 \mathrm{a}$ & $4.90 \mathrm{a}$ & $5.30 \mathrm{a}$ & 0.1734 \\
\hline Protein $\left(\mathrm{mg} \mathrm{l}^{-1}\right)$ & $2.60 \mathrm{a}$ & $0.53 \mathrm{~b}$ & $0.86 \mathrm{C}$ & $<0.0001$ \\
\hline Lysozyme $\left(\mathrm{mg} \mathrm{l}^{-1}\right)$ & $14.41 \mathrm{a}$ & $8.62 \mathrm{~b}$ & $9.04 \mathrm{~b}$ & $<0.0001$ \\
\hline THC (cell ml-1) & $1.8 \times 10^{6} \mathrm{a}$ & $1.7 \times 10^{6} \mathrm{~b}$ & $3.2 \times 10^{6} \mathrm{C}$ & $<0.0001$ \\
\hline \multicolumn{5}{|l|}{ Palizada } \\
\hline Condition index & $5.50 \mathrm{a}$ & $5.60 \mathrm{a}$ & $5.20 \mathrm{a}$ & 0.1498 \\
\hline Agglutination titer & $4.90 \mathrm{a}$ & $4.90 \mathrm{a}$ & $4.30 \mathrm{a}$ & 0.5166 \\
\hline Protein $\left(\mathrm{mg} \mathrm{l}^{-1}\right)$ & $7.55 \mathrm{a}$ & $3.18 \mathrm{~b}$ & $0.66 \mathrm{C}$ & $<0.0001$ \\
\hline Lysozyme $\left(\mathrm{mg} \mathrm{l}^{-1}\right)$ & $14.52 \mathrm{a}$ & $3.97 \mathrm{~b}$ & $3.89 \mathrm{~b}$ & $<0.0001$ \\
\hline THC (cell ml ${ }^{-1}$ ) & $3.8 \times 10^{6} \mathrm{a}$ & $7.9 \times 10^{5} \mathrm{~b}$ & $3.2 \times 10^{6} \mathrm{C}$ & $<0.0001$ \\
\hline \multicolumn{5}{|l|}{ Panlau } \\
\hline Condition index & $6.00 \mathrm{a}$ & $1.80 \mathrm{~b}$ & $2.40 \mathrm{C}$ & $<0.0001$ \\
\hline Agglutination titer & $5.30 \mathrm{a}$ & $4.90 \mathrm{~b}$ & $3.30 \mathrm{~b}$ & $<0.0001$ \\
\hline Protein $\left(\mathrm{mg} \mathrm{l}^{-1}\right)$ & $6.11 \mathrm{a}$ & $0.53 \mathrm{~b}$ & $0.49 \mathrm{~b}$ & $<0.0001$ \\
\hline Lysozyme $\left(\mathrm{mg} \mathrm{l}^{-1}\right)$ & $13.73 \mathrm{a}$ & $3.75 \mathrm{~b}$ & $4.62 \mathrm{~b}$ & $<0.0001$ \\
\hline THC (cell ml $\left.{ }^{-1}\right)$ & $3.0 \times 10^{6} \mathrm{a}$ & $7.5 \times 10^{5} \mathrm{~b}$ & $3.6 \times 10^{6} \mathrm{a}$ & $<0.0001$ \\
\hline \multicolumn{5}{|l|}{ Playaso } \\
\hline Condition index & $4.70 \mathrm{a}$ & $2.70 \mathrm{~b}$ & $4.10 \mathrm{c}$ & $<0.0001$ \\
\hline Agglutination titer & $5.30 \mathrm{a}$ & $4.30 \mathrm{a}$ & $3.30 \mathrm{a}$ & 0.2985 \\
\hline Protein $\left(\mathrm{mg} \mathrm{l}^{-1}\right)$ & $2.60 \mathrm{a}$ & $0.67 \mathrm{~b}$ & $4.44 \mathrm{a}$ & $<0.0001$ \\
\hline Lysozyme $\left(\mathrm{mg} \mathrm{l}^{-1}\right)$ & $15.09 \mathrm{a}$ & $7.88 \mathrm{~b}$ & $8.35 \mathrm{~b}$ & $<0.0001$ \\
\hline THC (cell ml ${ }^{-1}$ ) & $3.6 \times 10^{6} \mathrm{a}$ & $1.6 \times 10^{6} \mathrm{~b}$ & $3.0 \times 10^{6} \mathrm{C}$ & $<0.0001$ \\
\hline \multicolumn{5}{|l|}{ San Francisco } \\
\hline Condition index & $4.30 \mathrm{a}$ & $3.70 \mathrm{~b}$ & $4.70 \mathrm{a}$ & 0.0329 \\
\hline Agglutination titer & $5.30 \mathrm{a}$ & $4.30 \mathrm{~b}$ & $4.30 \mathrm{~b}$ & $<0.0001$ \\
\hline Protein $\left(\mathrm{mg} \mathrm{l}^{-1}\right)$ & $2.83 \mathrm{a}$ & $0.59 \mathrm{~b}$ & $1.00 \mathrm{C}$ & $<0.0001$ \\
\hline Lysozyme $\left(\mathrm{mg} \mathrm{l}^{-1}\right)$ & $14.57 \mathrm{a}$ & $7.94 \mathrm{~b}$ & $9.63 \mathrm{~b}$ & $<0.0001$ \\
\hline THC (cell ml $\left.{ }^{-1}\right)$ & $3.2 \times 10^{6} \mathrm{a}$ & $1.6 \times 10^{6} \mathrm{~b}$ & $3.0 \times 10^{6} \mathrm{a}$ & $<0.0001$ \\
\hline
\end{tabular}

\section{DISCUSSION}

The prevalence of Perkinsus marinus in Terminos Lagoon exhibited a strong seasonal pattern reflecting the influence of environmental conditions on the infection. Although temperatures and salinities were high enough to support a seasonal outbreak, $P$. marinus was not associated with disease in Terminos Lagoon during the study period. The difference in seasonal oyster mortality was attributed to the direct effect of environmental conditions on oyster physiology. Even though previous studies reported $P$. marinus from the Mexican coast, little research has been done over a long-term period in this tropical area. When the parasite was discovered by Burreson et al. (1994) in Tabasco, few samples were assayed (mainly gapers), and despite the high prevalence (60 to $100 \%$ ), the infection intensity was light to moderate except in one location in Machona Lagoon. Because water samples and/ or hemolymph were not collected, it is difficult to draw a definite conclusion about different environmental or physiological conditions with respect to Terminos Lagoon. To date, no serious $P$. marinus epizootic has been reported in Mexican lagoons; however, the pattern of high prevalence and light infection intensity found in the present study is consistent with previous findings in the field by Aguirre-Macedo et al. (2000) in 8 Mexican coastal lagoons.

We observed the absence of a direct relationship between weighted prevalence and temperature, in contrast with the US Gulf of Mexico, where multi-year climate cycles have a significant influence on Perkinsus marinus prevalence and infection intensity (Powell et al. 1996). On the southern Mexican coast, the seasonality related to temperature is not evident (annual mean, $28 \pm 3^{\circ} \mathrm{C}$ ). However, since previous studies from temperate climates showed that $P$. marinus sporulation in seawater occurs from 2 to 4 d at $28^{\circ} \mathrm{C}$ (Chu \& Green 1989) and even very light infections can increase to lethal levels in a $30 \mathrm{~d}$ period at $25^{\circ} \mathrm{C}$ (Fisher et al. 1992, Ragone Calvo \& Burreson 1994, Brousseau \& Baglivo 2000), we had expected to find high weighted prevalence in Terminos Lagoon, at least in high salinity sites. In the dry season, with the onset of warmer temperature $\left(29 \pm 2{ }^{\circ} \mathrm{C}\right)$ and higher salinity conditions $(29 \pm 10 \mathrm{psu})$ during 4 consecutive months, the low P. marinus intensity (Mackin scale <1) in the oyster population is surprising. Similar results 


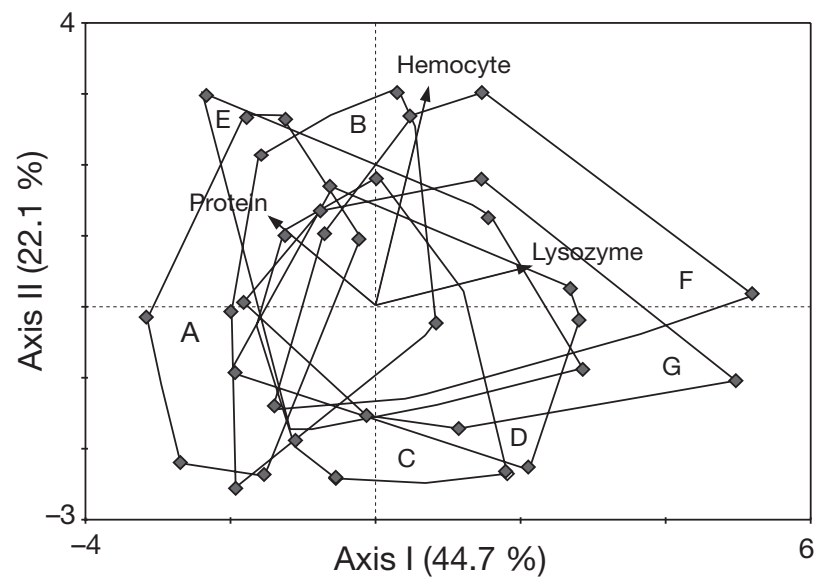

Fig. 4. Crassostrea virginica. Canonical variant analysis (CVA) based on 4 physiological variables (lysozyme and protein concentration, agglutination, hemocyte density) of dry season oysters $(n=315)$. Arrows: significant physiological variables (Monte Carlo test with 5000 permutations, $\mathrm{p}=$ 0.001). Diagram was adjusted by differentiating polygons representing different oyster beds. Letter inside each polygon indicates the oyster site name. A: Estero Pargo; B: Palizada; C: La Isla; D: Balchacah; E: San Francisco; F: Playaso; G: Panlau. Eigenvalues for Axes I and II shown in parentheses

were found by Aguirre-Macedo et al. (2007), who observed low P. marinus intensity (Mackin scale <1) in the dry and rainy seasons in Terminos Lagoon, with 80 and $50 \%$ prevalence, respectively. On the other hand, the correlation reported by Burreson \& Ragone Calvo (1996) between water temperature and $P$. marinus intensity approximately 2 to 3 mo after the annual temperature maximum was not evident in this tropical climate. Our results suggest that other environmental factors are controlling $P$. marinus intensity in tropical climates, without eliminating the possibility of race variation of either host or parasite due to different environmental adaptations, as has been suggested by other authors (Bushek \& Allen 1996, Gaffney \& Bushek 1996).

Our results show that inter-seasonal variation in salinity, although important, is not enough to explain the decreased prevalence in the rainy and north-wind seasons, and suggest that inter-seasonal nutrient levels play an important role in Perkinsus marinusweighted prevalence. The GLM (Fig. 3) shows that together with the positive correlation with salinity, $P$. marinus prevalence has an important negative correlation with SRSi and SRP. On the Atlantic coast of the US, $P$. marinus appears tolerant to salinities as low as 6 psu, and $>12$ psu is usually described as the salinity required for lethal infections (Ford \& Tripp 1996). In tropical climates, the interaction between $P$. marinus prevalence and salinity seems to be differ- ent. In the dry season, high prevalence in sampling sites was expected considering the high salinity $(29 \pm$ $10 \mathrm{psu})$ and temperature $\left(29 \pm 2{ }^{\circ} \mathrm{C}\right)$ conditions. However, in the rainy season when the prevalence decreased, the salinity change did not suffice to explain the decrease at Estero Pargo (marine site) and at Playaso (Table 1), where the salinity and temperature conditions remained high enough for $P$. marinus replication (Table 2). Some authors have emphasized that, although important, temperature and salinity do not explain most of infection levels observed in the field, suggesting water quality as a possible influence of P. marinus prevalence (Soniat 1985, Craig et al. 1989). According to La Peyre et al. (2003), the repetitive and well-timed freshet can maintain $P$. marinus infections at non-lethal intensities. Moreover, in Terminos Lagoon, the freshwater inputs carry high nutrient concentrations (SRP, SRSi) from the lowlands of Tabasco and the highlands of Chiapas (Yáñez-Arancibia et al. 1983, Ramos-Miranda et al. 2006) that could be controlling $P$. marinus replication. In this context, it is very difficult to define with precision the importance of each nutrient separately when the variables are observed in nature; nevertheless, our data suggest that in Terminos Lagoon, $P$. marinus replication is controlled at least by the combination of the water parameters measured in this study, if not by an even more complex set of parameters.

Our data support that inter-seasonal salinity variation and inter-seasonal nutrient levels have important effects on the oyster's physiological condition. Oyster populations at all sites showed a seasonal pattern in $\mathrm{CI}$ and protein concentration with the highest values in the dry season and the lowest in the rainy season (Table 4), suggesting that dry season conditions favor oyster growth. Mortality was higher in rainy and north-wind seasons than in the dry season (Table 3). Since Perkinsus marinus weighted prevalence was $<1.0$ during the study year, it is unlikely that oyster mortality in the rainy season is associated with the parasite (Andrews 1988). Because temperature in tropical areas is not a stress factor for Crassostrea virginica survival (Helm et al. 2004), the inter-seasonal salinity variation, especially from the dry $(29 \pm 10 \mathrm{psu})$ to the rainy season $(8 \pm 8 \mathrm{psu})$ seems to be the main factor associated with mortality. Oyster mortality from excessive freshwater runoff has been reported by several authors (Caffey \& Schexnayder 2002, Volety et al. 2003, Tolley \& Volety 2005), and this situation is exacerbated when periods of runoff coincide with periods of high temperature because of metabolic energy demands (Shumway 1996). Therefore, one could conclude that oysters that die during this rainy period are the most infected; however, the low P. marinus intensity before the freshwater input, added to the reduc- 
tion in the oyster $\mathrm{CI}$ in the rainy season, greatly limit the applicability of this hypothesis. In addition, mortality from the rainy season and the fact that re-establishment of parasite populations lag behind the reestablishment of host populations (Ray 1987) would be the cause of the low prevalence in the subsequent north-wind season (Table 1).

Establishing a correlation between physiological parameters and disease status was difficult in this fieldwork because of the light infection intensity registered. CVA confirmed that the physiological condition of the oyster population was the same independent of the bed location (Fig. 4). By observing the trend of the humoral oyster parameters, the ordination diagram showed a weak association between Perkinsus marinus intensity and physiological parameters (Axis I explained only $34 \%$ of the association). The conditional effects show protein and lysozyme as main parameters associated with the dry season, where the salinity condition was significantly high. It is probable that environmental variables have a more important influence over the physiological parameters than $P$. marinus infection. In the future, it will be invaluable to study these physiological and immunological parameters in oyster populations with moderate to heavy $P$. marinus infections to clarify doubts regarding their contribution to defense against the parasite in tropical climates. Nevertheless, the information collected in this study includes a useful first description of Crassostrea virginica health in the tropical areas of the Gulf of Mexico.

Based on our discrete seasonal sampling, the results show epizootiological differences between Perkinsus marinus behavior in tropical and temperate climates. Our data support the fact that changes in salinity exert an important effect on both the parasite and the oysters' physiological condition, and suggests that freshwater input, which results in high SRP and SRSi concentrations, are controlling the $P$. marinus weighted prevalence in the Terminos Lagoon. The data reported here further contribute to the characterization of perkinsosis in tropical climates but do not refute the likelihood that other factors associated with the host, parasite, or environment can influence the epizootiology of $P$. marinus on the Mexican coast.

Acknowledgements. We thank G. Arjona., R. Sima, E. Mendoza, and J. Ek from the CINVESTAV Aquatic Pathology Laboratory, and G. Rivas from UNACAR for logistic support with fieldwork. We are grateful to Dr. E. Burreson (Virginia Institute of Marine Science) and Dr. V. Vidal (CINVESTAV) for their critical review and constructive comments on the manuscript. We also thank J. Montero for statistical assistance. We acknowledge CONACYT for a PhD scholarship awarded to M.G.K. This research was partially supported by CONACYT (grant no. 26-322N to L.A.M.) and CONAPESCA.

\section{LITERATURE CITED}

Aguirre-Macedo ML, Román-Magaña MK, Simá-Alvarez RA, Güemez-Ricalde JL (2000) Parasitofauna del ostión americano (Crassostrea virginica) en el golfo de México. Memorias del 1er Congreso de Responsables de Proyectos de Investigación en Ciencias Naturales. CONACYT, Veracruz, p 1-10

Aguirre-Macedo ML, Simá-Álvarez RA, Román-Magaña MK, Güemez-Ricalde JI (2007). Parasite survey of the eastern oyster Crassostrea virginica in coastal lagoons of the southern Gulf of Mexico. J Aquat Anim Health 19:270-279

Amador del Angel LE, Cabrera-Rodríguez P, Guevara-Carrió E, Casanova M, Laynes M (2003) Evaluación preliminar del crecimiento y sobrevivencia del ostión (Crassostrea virginica Gmelin, 1791) en la Laguna de Términos, Campeche (México). II Congreso Iberoamericano Virtual de Acuicultura. CIVA 2002 (www.civa2003.org) p 237-244

Andrews JD (1988) Epizootiology of the disease caused by the oyster pathogen Perkinsus marinus and its effects on the oyster industry. Am Fish Soc Spec Publ 18:23-37

Audemard C, Ragone-Calvo LM, Paynter KT, Reece KS, Burreson EM (2006) Real-time PCR investigation of parasite ecology: in situ determination of oyster parasite Perkinsus marinus transmission dynamics in lower Chesapeake Bay. Parasitology 132:827-842

Bach L, Calderon R, Cepeda MF, Oczkowski A, Olsen SB, Robadue D (2005) Resumen del perfil de primer nivel del sitio Laguna de Términos y su cuenca, México. Coastal Resources Center, University of Rhode Island, Narragansett, RI

Brousseau DJ, Baglivo JA (2000) Modeling seasonal proliferation of the parasite Perkinsus marinus (Dermo) in field populations of the oyster, Crassostrea virginica. J Shellfish Res 19:133-138

Burreson EM, Ragone Calvo LM (1996) Epizootiology of Perkinsus marinus disease of oysters in Chesapeake Bay, with emphasis on data since 1985. J Shellfish Res 15:17-34

- Burreson E, Alvarez R, Martinez V, Macedo L (1994) Perkinsus marinus (Apicomplexa) as a potential source of oyster Crassostrea virginica mortality in coastal lagoons of Tabasco, Mexico. Dis Aquat Org 20:77-82

Bushek D, Allen SK (1996) Races of Perkinsus marinus. J Shellfish Res 15:103-107

Bushek D, Ford S, Allen SK Jr (1994) Evaluation of methods using Ray's fluid thioglycollate medium for diagnosis of Perkinsus marinus infection in the Eastern oyster, Crassostrea virginica. Annu Rev Fish Dis 4:201-207

Cabrera RP, Aranda D, Amador del Angel L (1999) Producción ostrícola de Crassostrea virginica en el Área Natural de Protección de Flora y Fauna Laguna de Términos, Campeche, México. Resúmenes $29^{\text {na }}$. Reunión Asociación de Laboratorios Marinos del Caribe (ALMC), IOV, Cumaná, p 4

Caffey RH, Schexnayder M (2002) Fisheries implications of freshwater reintroductions. In: Coastal Wetland Planning, Protection, and Restoration Act (eds) An interpretive topic series on coastal wetland restoration in Louisiana. National Sea Grant Library No. LSU-G-02-003, p 1-8

Carnegie R, Burreson E (2005) Status of the major oyster diseases in Virginia 2004. A summary of the annual monitoring program. Virginia Institute of Marine Science, Gloucester Point, VA

Choi KS, Park KI, Li KW, Matsuoka K (2002) Infection intensity, prevalence, and histopathology of Perkinsus sp. in the Manila clam, Ruditapes philippinarum, in Isahaya Bay, Japan. J Shellfish Res 21:119-125 
Chu FLE, Green KH (1989) Effect of temperature and salinity on in vitro culture of the oyster pathogen, Perkinsus marinus (Apicomplexa: Perkinsea). J Invertebr Pathol 53: 260-268

Chu FLE, La Peyre JF (1993) Perkinsus marinus susceptibility and defense-related activities in eastern oysters Crassostrea virginica: temperature effects. Dis Aquat Org 16: 223-234

Craig A, Powell EN, Fay RR, Brooks JM (1989) Distribution of Perkinsus marinus in Gulf Coast oyster populations. Estuaries 12:82-91

David LT, Kjerfve B (1998) Tides and currents in a two-inlet coastal lagoon: Laguna de Términos, México. Cont Shelf Res 18:1057-1079

Fisher WS, DiNuzzo AR (1991) Agglutination of bacteria and erythrocytes by serum from six species of marine mollusks. J Invertebr Pathol 57:380-394

Fisher WS, Gauthier JD, Winstead JT (1992) Infection intensity of Perkinsus marinus disease in Crassostrea virginica (Gmelin, 1791) from the Gulf of Mexico maintained under different laboratory conditions. J Shellfish Res 11:363-369

Ford SE, Tripp MR (1996) Diseases and defense mechanisms. In: Kennedy VS, Newell RIE, Eble AF (eds) The eastern oyster, Crassostrea virginica. Maryland Sea Grant Books, Annapolis, MD, p 581-660

Gaffney PM, Bushek D (1996) Genetic aspects of disease resistance in oysters. J Shellfish Res 15:135-140

Galtsoff PS (1964) The American oyster. Fish Wildl Serv Fish Bull 64:1-480

Gold-Bouchot G, Barroso-Noreña L, Zapata-Perez O (1995) Hydrocarbon concentrations in the American oyster (Crassostrea virginica) in Laguna de Terminos, Campeche, Mexico. Bull Environ Contam Toxicol 53: 222-227

Helm MM, Bourne N, Lovatelli A (2004) Hatchery culture of bivalves. A practical manual. FAO Fish Tech Pap 471

Karolus J, Sunila I, Spear S, Volk J (2000) Prevalence of Perkinsus marinus (Dermo) in Crassostrea virginica along the Connecticut shoreline. Aquaculture 183:215-221

La Peyre MK, Nickens AD, Volety AK, Tolley GS, La Peyre JF (2003) Environmental significance of freshets in reducing Perkinsus marinus infection in eastern oysters Crassostrea virginica: potential management applications. Mar Ecol Prog Ser 248:165-176

Legendre P, Legendre L (1998) Numerical ecology, 2nd English edn. Elsevier Science BV, Amsterdam

Lenihan HS, Micheli F, Shelton SW, Peterson CH (1999) The influence of multiple environmental stressors on susceptibility to parasites: an experimental determination with oysters. Limnol Oceanogr 44:910-924

Leps J, Smilauer P (2003) Multivariate analysis of ecological data using CANOCO. Cambridge University Press, New York

> Lowry OH (1951) Protein measurement with folin phenol reagent. J Biol Chem 193:265-275

MacKenzie CL, Wakida-Kusunoki AT (1997) The oyster industry of Eastern Mexico. Mar Fish Rev 59:1-13

Mackin JG (1962) Oyster disease caused by Dermocystidium marinum and other microorganisms in Louisiana. Publ Inst Mar Sci Univ Tex 7:132-229

Marsh AG, Gauthier JD, Vasta GR (1995) A semiquantitative PCR assay for assessing Perkinsus marinus infections in the eastern oyster, Crassostrea virginica. J Parasitol 81:577-583

Martínez I, Aldana D, Brulé T, Cabrera E (1995) Crecimiento y desarrollo gonadal del ostión Crassostrea virginica
(Gmelin, 1791) (Mollusca:Ostreidae), en la Peninsula de Yucatán, México. Avicennia 3:61-75

McCullagh P, Nelder J (1989) Generalized linear models, 2nd edn. Chapman \& Hall, London

Powell EN, Klinck JM, Hofmann EE (1996) Modeling diseased oyster populations. II. Triggering mechanisms for Perkinsus marinus epizootics. J Shellfish Res 15:141-165

Ragone Calvo LM, Burreson EM (1994) Characterization of overwintering infections of Perkinsus marinus (Apicomplexa) in Chesapeake Bay oysters. J Shellfish Res 13: 123-130

Ragone Calvo LM, Burreson EM (2003) Status of the major oyster diseases in Virginia - 2002. A summary of the annual monitoring program. Virginia Institute of Marine Science Marine Resource Report, Gloucester Point, VA

Ragone Calvo LM, Wetzel RL, Burreson EM (2000) Development and verification of a model for the population dynamics of the protistan parasite, Perkinsus marinus, within its host, the eastern oyster, Crassostrea virginica, in Chesapeake Bay. J Shellfish Res 20:231-241

Ramos-Miranda J, Flores-Hernández D, Ayala-Pérez LA, Rendón-von-Osten J, Villalobos-Zapata G, Sosa-López A (2006) Atlas hidrológico e ictiológico de la Laguna de Términos. Universidad Autónoma de Campeche, Campeche

Ray SM (1966) A review of the culture method for detecting Dermocystidium marinum, with suggested modifications and precautions. Proc Natl Shellfish Assoc 54:55-69

Ray SM (1987) Salinity requirements of the American oyster, Crassostrea virginica. In: Mueller AJ, Matthews GA (eds) Freshwater inflow needs of the Matagorda Bay system with focus on penaeid shrimp. US Dept Comm, Natl Oceanic Atmos Admin Tech Mem NMFS-SEFC-189, Galveston, TX, p E.1-E.28

Robledo JAF, Gauthier JD, Coss CA, Wright AC, Vasta GR (1998) Species-specificity and sensitivity of a PCR-based assay for Perkinsus marinus in the eastern oyster, Crassostrea virginica: a comparison with the fluid thioglycollate assay. J Parasitol 84:1237-1244

Robledo JAF, Wright AC, Marsh AG, Vasta GR (1999) Nucleotide sequence variability in the nontranscribed spacer of the rRNA locus in the oyster parasite Perkinsus marinus. J Parasitol 85:650-656

Rogers P, García-Cubas (1981) Evolución gonádica a nivel histológico del ostión Crassostrea virginica (Gmelin 1791) del sistema fluvio lagunar Atasta Pom, Laguna de Términos Campeche, México. An Inst Cienc Mar Limnol 8:21-42

Sambrook J, Fritsch E, Maniatis T (1989) Molecular cloning: a laboratory manual, 2nd edn. Cold Spring Harbor Laboratory Press, Woodbury, NY

Shumway SE (1996) Natural environmental factors. In: Kennedy VS, Newell RIE, Eble AF (eds) The eastern oyster, Crassostrea virginica. Maryland Sea Grant Books, Annapolis, MD p 467-513

Solorzano L, Sharp JH (1980) Determination of total dissolved phosphorus and particulate phosphorus in natural waters. Limnol Oceanogr 25:754-758

Soniat TM (1985) Changes in levels of infection of oysters infected by Perkinsus marinus, with special reference to the interaction of temperature and salinity upon parasitism. Northeast Gulf Sci 7:171-174

Strickland JD, Parsons TR (1972) A practical handbook of seawater analysis. Bull Fish Res Board Can 167:107-112

Ter Braak CJ, Smilauer P (2002) CANOCO reference manual and CanoDraw for Windows, user's guide: software for canonical community ordination (version 4.5). Microcomputer Power, Ithaca, NY 
Tolley SG, Volety AK (2005) The role of oysters in habitat use of oyster reefs by resident fishes and decapod crustaceans. J Shellfish Res 24:1007-1012

Volety AK, Tolley SG, Winstead J (2003) Investigations into effects of seasonal and water quality parameters on oysters (Crassostrea virginica) and associated fish populations in the Caloosahatchee Estuary. Interpretive Report (Award \#C 12412-A 1), South Florida Water

Editorial responsibility: Stephen Feist, Weymouth, UK
Management District, West Palm Beach, FL

Yáñez-Arancibia A, Day JW (1988) Ecology of coastal ecosystems in the southern Gulf of Mexico: the Términos Lagoon region. UNAM, Mexico, DF

Yáñez-Arancibia A, Lara-Domíguez AL, Chavance $\mathrm{P}$, Hernández DF (1983) Environmental behavior of Terminos Lagoon ecological system, Campeche, Mexico. An Inst Cienc Mar Limnol 10:137-176

Submitted: October 31, 2007; Accepted: February 22, 2008 Proofs received from author(s): April 17, 2008 